\title{
Sustainable Development Innovation "The Effect of Flexible HRM Behavior on SME Innovation"
}

\author{
$\underline{\text { Rodhiah }}^{1}$, Nur Hidayah ${ }^{2}$ \\ 1,3Faculty of Economics \& Business, Universitas Tarumanagara Jakarta, Indonesia \\ Email: rodhiah@fe.untar.ac.id, nurh@fe.untar.ac.id
}

\begin{abstract}
:
Through the results of the 2020 Higher Education grant research, shows the need for sustainable innovation development in SMEs through the development of the competence of creative resources owned by SMEs. These resources need support from human resource management, because it is a business strategy that effectively supports innovation. This study aims to determine the effect of flexible human resources, innovative work behavior and SME innovation. Researched as many as 100 SMEs creative products spread across the province of Banten. The study used convenience sampling as a sample. The data collection technique was by distributing questionnaires by directly coming to SMEs. The results of the study show that flexible resource management has a positive and significant effect on SME innovation, and on innovative work behavior. Flexible human resource management has no positive and insignificant effect on SME innovation with innovative work behavior as a mediating variable.
\end{abstract}

\section{Keywords:}

flexible human resource management; innovative work behavior; SME innovation

\section{Introduction}

The journey of a business cannot be separated from the problem of creative and innovative human resources, this is important in increasing business sustainability. A company following a creative and innovative strategy must have employees who bring innovative work behavior (Eenink, 2012).

It is important for SMEs to have the ability to keep up with changes in introducing new product ideas. Accroding to Jiang (2012), a company must have innovative entrepreneurial behavior, and increase the competence of an organization to be more proactive, so that it becomes a strong impetus for sustainable business innovation. The continuous innovation of an organization can be measured by the presence of innovative and proactive resource capabilities. An innovative business strategy requires flexible human resource management, because SMEs quickly adapt to changes that occur. Generally a business will experience uncertainty from both internal and external factors in the business environment (Kumari \& Pradhan, 2014). Flexible human resource management (FHRM) has an influence on innovative work behavior as targeted towards improving employee skills, motivation, abilities and opportunities (Puikene, 2016). FHRM basically empowers employees to showcase their talents and deliver results in the form of innovative ideas with their skills and abilities. (Prieto \& Perez-Santana, 2013). Basically, innovative work behavior is very important for innovation-seeking SMEs because the success of innovative SMEs lies in their 


\section{Economit Journal: Scientific Journal of Accountancy, Management and Finance ISSN: 2775-5827 (Online), 2775-5819 (Print)}

Vol. 1, No. 4, November 2021, Page: 231-240

Email: economitjournal@gmail.com

employees whose behavior is the most important source to lead innovation. (Abstein \& Spieth, 2014).

According to European Comission (2020), Commissioner Hahn has called for an extensive consultation process, which provides the opportunity for all staff and stakeholders to put forward their views to enrich the current development. DG HR is organising a series of workshops, presentations, and group and individual interviews with all levels of staff, to ensure that the new strategy meets the needs of both staff and the organisation. We are also looking outside the organisation and benchmark with other institutions, HR departments in Member States, and HR Professional bodies. The consultation process started in June 2020 and continued throughout the summer. On the basis of the outcomes of the various workshops, surveys and interviews, DG HR is consolidating the findings and identifying the main focus areas of the strategy. The current strategic plan is based on these initial inputs. HR managers are further analysing the proposed initiatives under each focus area, again with input from staff at all levels, with a view to developing a road map for each of the HR Domains, and will adapt the strategic plan 2020-2024 accordingly. The new HR strategy will be in place as from Q1 2021.

Although the role of human resource management in innovation has produced many outputs from academic circles (Karlsson, 2013; Zhou, 2018, Jiang, Wang \& Zhao, 2012) and some have also tested it empirically (Jimenez \& Valle, 2008) although these studies have not clarified the types of HR practices that make organizations innovative. Furthermore, several studies that mention flexible human resources (Kumara \& Pradhan, 2014: Chang et al, 2013) still have shortcomings, especially regarding the perspective of employee behavior towards SME innovation. The basic objective of this study is to examine the effect of flexible human resource management, innovative work behavior and SME innovation which are interrelated in enhancing the innovative ability of SMEs.

\section{Review of Literature}

\subsection{Flexible Human Resources}

Flexible HRM is an important element of strategic HR, it is an internal capability of the company and is considered a prerequisite for sustainable competitive advantage (Kozica \& Kaiser, 2012). Flexible human resources investigates the extent to which a company can quickly and effectively adapt according to a changing environment (Chen \& Li, 2015). The concept of flexible HRM was created in 1995. Organizations use flexibility HRM to maintain employee motivation and performance (Herrbach, Mignonac, Vandenberghe, \& Negrini, 2009). However, because flexibility HRM has primarily been designed for middle-aged workers with children (Allen et al., 2013), it is necessary to investigate the effects of flexibility for younger generations, as well as older workers (Bal, De Jong, Jansen, \& Bakker, 2012; Kooij et al., 2013). To investigate this, it is essential to differentiate between the effects age can have on the outcomes of flexibility HRM. Both literatures on younger workers (e.g., Hess \& Jepsen, 2009; Lub, Bijvank, Bal, Blomme, \& Schalk, 2012) and older workers (Bal et al., 2012; PittCatsouphes \& Matz-Costa, 2008) have stressed the importance of flexibility in how employees conduct their work, and how work is combined with other aspects in life. Generation theory (Twenge et al., 2010, 2012) predicts that younger workers attach more value to flexibility at work and hence become more emotionally affected when they have flexibility. To counteract the negative consequences of age-related losses, older workers may use flexibility to maintain their performance. Lyons and Kuron (2014), in their recent review, concluded that saliency of flexibility and work-life balance has increased over generations, but at the same time, life-cycle 
effects also existed. They found that work-life balance has become more important among younger generations, but at the same time studies have shown curvilinear effects, indicating that work-life balance also becomes more important among older workers (Lyons \& Kuron, 2014). The current study specifically aims to unravel these different effects of employee age, by simultaneously hypothesizing and testing generation effects and aging effects.

\subsection{Innovative Work Behavior}

Innovative work behavior is defined as individual behavior in exploring, generating, fighting for and implementing effective ideas, products, processes or procedures (De Jong \& Den Hartog, 2010). Basically thinking about alternative methods, looking for improvements, looking for new technologies, ways to achieve tasks, trying new work methods and finding and securing useful resources to make ideas come true (Prieto \& Santana, 2013).

\subsection{SME Innovation}

Innovation is a key attitude in every management team and every SME for them to be innovative, thus coming up with new ideas for their SME's competitive advantage and resilience.

\subsection{Relationship between Variables and Hypotheses a. Flexible HRM to Innovative SMEs}

FHRM impacts SMEs innovation directly Flexible HRM enables organizations to acquire and develop a wide range of skills and behaviors (Chang et al, 2012).) Conducted research showing that Flexible HRM creates HR allocations that are very difficult to imitate thus enabling them to gain a competitive advantage sustainable. FHRM enables a fast and timely response through their employees to resolve demands or adapt to any conditions thus enabling long-term competitiveness (Nie, 2009) thus enabling the potential to broaden the range of capabilities needed to innovate (Sánchez et al, 2011).

H1: Flexible resource management is positively related to SME innovation

\section{b. HRM Flexible to Innovative Work Behavior}

Basically an organization where FHRM forms knowledge, skills and attitudes of employees according to various situations required is able to create more innovative employees (Puikene, 2016). Diversity in skills gives employees a sense of accomplishment, identity and self-development (Sánchez et al, 2011) which in turn has an indirect impact on the psychology of employees and makes them more confident to take innovative actions (Chen \& Li, 2015). Prieto and Perez-Santana (2013) conducted a study by taking a sample of 198 Spanish from a study that illustrates that skills have an impact on innovative work behavior boost and motivation. Organizations that bring flexibility in HR practices basically create an environment where their workforce can adapt to respond to environmental changes more dynamically (Kumara \& Pradhan, 2014). HR practices when their employees are flexible to act in every condition encourage diverse behaviors and versatility (Kumari \& Pradhan, 2014) gives them a sense of independence to act innovatively. Patterson et al (2010) explain that flexibility in HR practices can also encourage innovative work behavior, flexible HR practices provide employees with customizable work plans that make them motivated to do what the situation demands (Prieto \& Santana, 2013) then the research hypothesis is: Pradhan, 2014). HR practices when their employees are flexible to act in every condition encourage diverse and versatile behavior (Kumari \& Pradhan, 2014) give them a sense of independence to act innovatively. Patterson et al (2010) describe flexibility in HR practices can also encourage innovative work behavior, flexible HR practices provide employees with work plans that can 
be adjusted so that they are motivated to do what the situation demands (Prieto \& Santana, 2013) then the research hypothesis is:

H2: Flexible resource management positively influences innovative work behavior

\section{c. Flexible Human Resource Management towards SME Innovation with Innovative Work Behavior as a Mediation}

Patterson et al (2010) explain that flexibility in HR practices can also encourage innovative work behavior which ultimately encourages innovation. Organizations that bring flexibility in HR practices basically create an environment where their workforce can adapt to respond to environmental changes more dynamically (Kumari \& Pradhan, 2014). HR practices when their employees are flexible to act in every condition encourage diverse and versatile behavior (Kumari \& Pradhan, 2014) giving them a sense of independence to act innovatively. . Based on all the above literature shows that innovative work behavior plays an intermediary role between Flexible HRM and SME innovation. That is, it is assumed that behavior is influenced by flexible human resource management, while innovative work behavior itself affects SME innovation. Thus the proposed hypothesis is:

H3: Flexible human resource management has a significant influence on SME innovation with innovative work behavior as a mediating variable

\section{d. Innovative Work Behavior towards Innovation SMEs}

Innovative work behavior can shape how SMEs innovate. SME innovation relies heavily on organizational employees who are the main source of skills, knowledge and abilities and are the founders of innovative work behavior (Prieto \& Perez-Santana, 2013). To innovate timely and effectively in a competitive environment, organizations rely heavily on the generation of new ideas which are actually developed by SME individuals (Chen \& Huang, 2009). The research hypotheses are:

Hypothesis H4: Innovative work behavior positively affects SME innovation.

H1

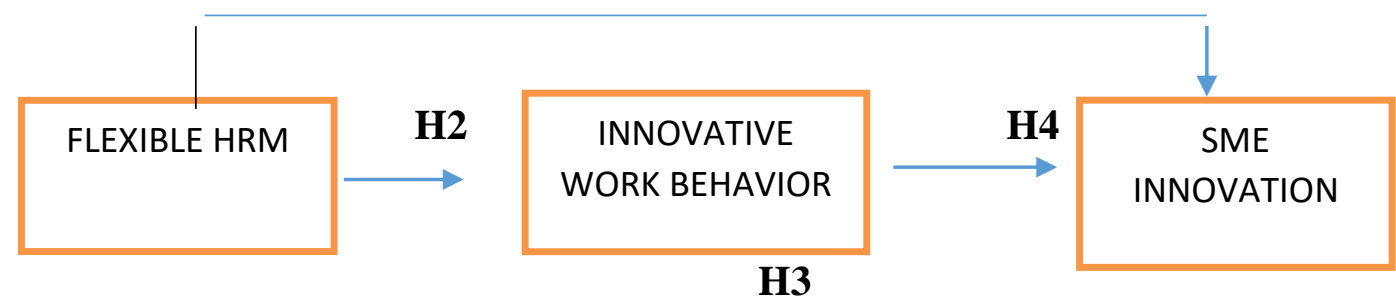

Figure 1. Research Model

\section{Research Methods}

This research is a descriptive researchwith a cross sectional approach. The population that will be involved is business people belonging to Small and Medium Enterprises (SMEs) in the South Tangerang area. Sampling with non-probability sampling method with convenience sampling method based onease of meeting SMEs as many as 100 samples.Collecting data by distributing questionnaires. In measuring FHRM, using the adopted and adjusted indicators from Bhattacharya. et al. (2005) collectively have 9 items. Firm Innovativeness: Stanley, Kam Sing Wong (2012) used 4 items to measure 
SME innovation. To measure innovative work behavior, the scale developed by Prieto \& Santana, (2013) has been used which has 5 items. The variables and indicators are

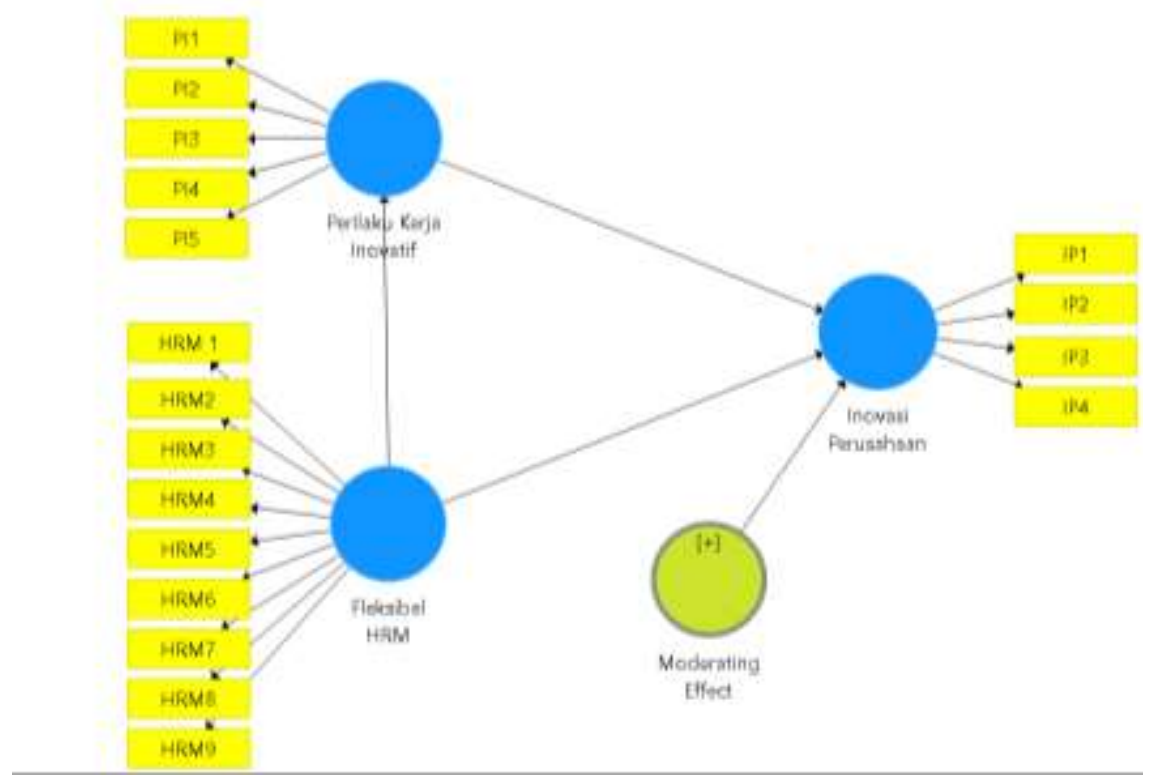

Figure 2. PLS Model Specifications

\section{Discussion}

\subsection{Results}

a. Respondent Profile

There are 100 respondents used in this study, the majority of respondents are female as much as $80 \%$, age between 30 to 40 years $50 \%$, S1 education level is $40 \%$, most types of business are culinary $45 \%$.

\section{b. Analysis}

Processing research data using PLS-SEM software which consists of two analyzes, namely the outer model and the inner model.

\section{c. Outer Model}

Based on the analysis of the results of the measurement model (Outer Model Analysis) it was found that all the indicators used to measure the research variables were valid and reliable so that they could represent the research variables and were trustworthy and reliable.

\section{Convergent Validity}

Table 1. AVE Score Result

\begin{tabular}{|c|c|}
\hline Variables / Dimensions & Average Variance Extracted \\
\hline Flexible HRM & 0.557 \\
\hline SME Innovation & 0.582 \\
\hline Innovation work behavior & 0.633 \\
\hline
\end{tabular}

It is known that the AVE value of each variable has a value above 0.5 which has met the convergent validity criteria as measured by the AVE value. This indicates that the variables in this study have met the criteria. 


\section{Discriminant Validity}

Table 2. Discriminant Validity

\begin{tabular}{|c|c|l|l|}
\hline & Flexible HRM & $\begin{array}{l}\text { SME } \\
\text { Innovation }\end{array}$ & $\begin{array}{l}\text { Innovative } \\
\text { work behavior }\end{array}$ \\
\hline $\begin{array}{c}\text { Flexible } \\
\text { HRM }\end{array}$ & 0.746 & 0.763 & \\
\hline $\begin{array}{c}\text { SME } \\
\text { Innovation }\end{array}$ & 0.638 & -0.378 & 0.796 \\
\hline $\begin{array}{c}\text { Moderating } \\
\text { Effect }\end{array}$ & -0.384 & 0.641 & \\
\hline $\begin{array}{c}\text { Innovative } \\
\text { work } \\
\text { behavior }\end{array}$ & 0.598 & & \\
\hline
\end{tabular}

From the results of the discriminant validity analysis in the table it shows that the value of the Heteroit-Monotrait Ratio on each indicator variable has a value less than $0.90(<0.90)$ so that all indicators of each variable can be accepted.

\section{Composite Reliability Test}

Sekaran and Bougie (2013) stated that the reliability of a measurement indicates that the indicator is consistent to be used from time to time. Testing reliability by looking at the value of composite reliability and Cronbach's Alpha. If each item used in measuring the variable has a composite reliability value $>0.60$ then the variable is declared reliable, if each item used in measuring the variable has a Cronbach's Alpha value $>0.60$ then the indicator or item to measure the variable is declared reliable. (Malhotra, 2020).

Table 3. Cronbach's Alpha and Composite Reliability

\begin{tabular}{|c|c|c|}
\hline Variable & Cronbach's Alpha & Composite Reliability \\
\hline Flexible HRM & 0.899 & 0.918 \\
\hline SME Innovation & 0.756 & 0.846 \\
\hline Moderating Effect & 1,000 & 1,000 \\
\hline $\begin{array}{c}\text { Innovation work } \\
\text { behavior }\end{array}$ & 0855 & 0.896 \\
\hline
\end{tabular}

From the results of the reliability analysis in the table, it shows that the value of Cronbach's Alpha and Composite Reliability on each variable indicator has a value greater than $0.60(>0.60)$ so that all indicators of each variable have met the requirements and are declared reliable.

\section{d. Inner Model}

\section{Coefficient of Determination Test (R2)}

\section{The Result of the Coefficient of Determination}

The value of R-Square (R2) is used to determine the coefficient of determination and measure the level of variation of changes in the independent variable to the dependent variable. The R-Square value has 3 criteria, namely as follows: a value of $0.75-1$ indicates (the influence is strong), a value of $0.5-0.74$ indicates (the influence is moderate), then a value of $0.25-0,49$ indicates (the influence is weak). 
Table 4. Coefficient of Determination $\boldsymbol{R}$-Square

\begin{tabular}{|c|c|}
\hline Variable & R-square \\
\hline SME Innovation & 0.514 \\
\hline
\end{tabular}

Based on the test results of the coefficient of determination (R2) shown in the table, it can be explained that the R-quare value for the SME innovation variable is 0.514 which means that $51.4 \%$ of the dependent variable of SME innovation can be explained by the variables in this study, the remaining $46.8 \%$ is explained by other variables not examined in this study.

\section{Inner Model Test}

Results from boostrapping is

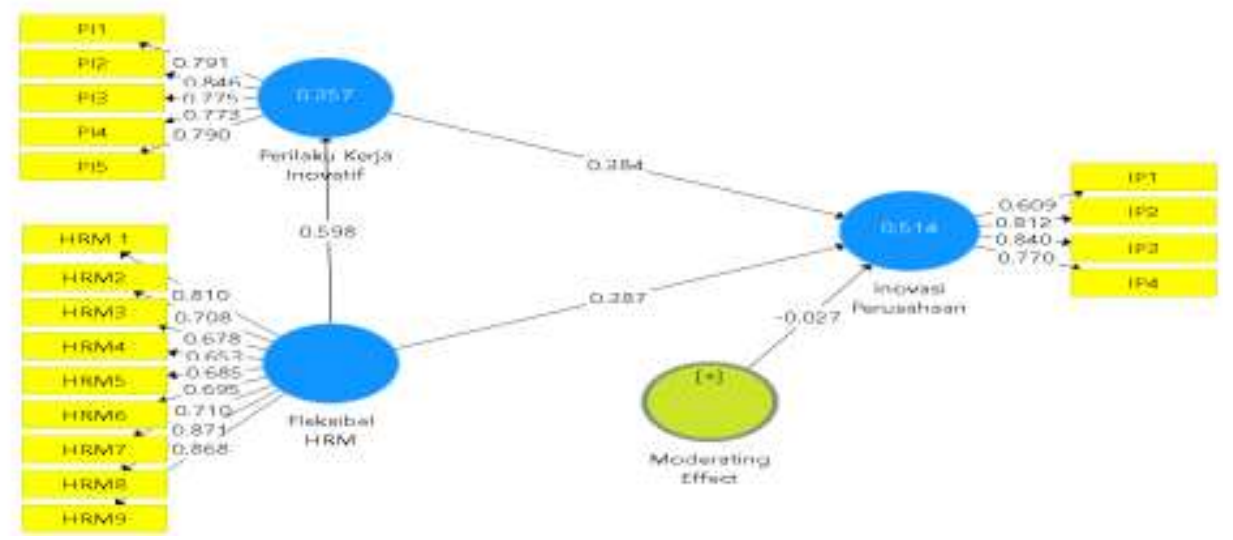

Figure 3. Boostrapping Test Results

Based on the results of the boostrapping test which can be seen in Figure 3, it can be summarized and presented in Table 6 to explain the results of the boostrapping.

Table 5. The Results of the Boostrapping

\begin{tabular}{|c|c|c|c|c|c|}
\hline & $\begin{array}{c}\text { Original } \\
\text { Sample } \\
(\boldsymbol{O})\end{array}$ & $\begin{array}{l}\text { Sample } \\
\text { Mean } \\
(\boldsymbol{M})\end{array}$ & $\begin{array}{l}\text { Standard } \\
\text { Deviation } \\
(\boldsymbol{S T D E V})\end{array}$ & $\begin{array}{c}\boldsymbol{t} \text { - } \\
\text { statistics }\end{array}$ & $p$-values \\
\hline Flexible HRM->SME Innovation & 0.387 & 0.385 & 0.080 & 4.855 & 0.000 \\
\hline $\begin{array}{c}\text { Feksibrel HRM->Innovative work } \\
\text { behavior }\end{array}$ & 0.598 & 0.606 & 0.087 & 6.897 & 0.000 \\
\hline $\begin{array}{c}\text { Moderating Effect -> Corporate } \\
\text { Innovation }\end{array}$ & -0.027 & -0.023 & 0.043 & 0.627 & 0.531 \\
\hline $\begin{array}{c}\text { Innovative work behavior -> } \\
\text { SME Innovation }\end{array}$ & 0.384 & 0.378 & 0.089 & 4.331 & 0.000 \\
\hline
\end{tabular}

Based on the results of testing the hypothesis above, the following test results are obtained:

1) In the path that shows the effect of Flexible HRM-> UKM Innovation, the p value obtained is 0.000 with a $\mathrm{T}$ statistic of 4.855 and a positive path coefficient of 0.387 . Because the path $\mathrm{p}$ value $<0.05$, T statistic $>1.96$ and the path coefficient is positive, it can be concluded that flexible HRM has a significant influence on SME innovation. This shows that research hypothesis 1 which says "Flexible resource management positively influences SME innovation" is accepted. 
2) In the path that shows the effect of HRM flexibility on innovative work behavior, the $\mathrm{p}$ value obtained is 0.000 with a $\mathrm{T}$ statistic of 6.897 and a positive path coefficient of 0.598 . Because the path $\mathrm{p}$ value $<0.05$, T statistic $>1.96$ and the path coefficient is positive, it can be concluded that flexible HRM has a significant effect on innovative work behavior. This shows that research hypothesis 2 which says "Flexible resource management positively influences innovative work behavior" is accepted.

3) In the path that shows the effect of innovative work behavior on SME innovation, the $\mathrm{p}$ value obtained is 0.000 with a $\mathrm{T}$ statistic of 4.311 and a positive path coefficient of 0.384 . Because the path $\mathrm{p}$ value $<0.05$, $\mathrm{T}$ statistic $>1.96$ and the path coefficient is positive, it can be concluded that innovative work behavior has a significant influence on SME innovation. This shows that research hypothesis 4 which says "Innovative work behavior has a positive effect on SME innovation.

\subsection{Discussion}

SMEs must have innovative entrepreneurial behavior, and increase my resource competence of an organization to be more proactive. For this reason, an innovative business strategy requires flexible human resources, who can quickly adapt to changes that occur, the tendency of a business to face uncertainty from both internal and external factors in the business environment (Kumari \& Pradhan, 2014). Flexible human resource management (FHRM) has an influence on SME innovation (Prieto \& Perez-Santana, 2013). This is in line with the results of this study which show that there is an influence between flexible HRM on SME innovation. Meanwhile, flexible human resource management (FHRM) innovative work behaviors such as those targeted at improving skills, motivation, capabilities and opportunities of employees (Puikene, 2016; Prieto \& Perez-Santana, 2013). Patterson et al (2010) explain that flexibility in HR practices can also encourage innovative work behavior, flexible HR practices provide employees with work plans that can be adjusted so that they are motivated to do what the situation demands (Prieto \& Santana, 2013). The results of this study support the previous findings, where the test results of this study show that there is an influence between flexible human resource management (FHRM) on innovative work behavior.

Basically, innovative work behavior is very important for innovation-seeking SMEs because the success of innovative SMEs lies in their employees whose behavior is the most important source to lead innovation. (Abstein \& Spieth, 2014). Innovative work behavior plays an intermediary role between Flexible HRM and SME innovation. That is, it is assumed that behavior is influenced by flexible human resource management, while innovative work behavior itself affects SME innovation. This is not in line with this study where flexible human resource management does not have a significant effect on SME innovation with innovative work behavior as a mediating variable. Innovative work behavior can shape the innovation of SMEs.

\section{Conclusions}

From the discussion above, there are some relevant conclusions. The first is the flexible resource management has a positive and significant impact on SME innovation. The second is Flexible resource management has a positive and significant effect on innovative work behavior. The third is flexible human resource management has no positive and insignificant effect on SME innovation with innovative work behavior as a mediating variable then the innovative work behavior has a positive and significant effect on SME innovation. 


\section{References}

Abstein, A., Heidenreich, S., \& Spieth, P. (2014). Innovative Work Behaviour: The impact of Comprehensive HrSystem Perceptions and the role of Work-Life Conflict. Industry and Innovation, 21(2), 91-116.

Allen, T.D., Johnson, R.C., Kiburz, K.M., \& Shockley, K.M. (2013). Work-family conflict and flexible work arrangements: deconstructing flexibility. Personnel Psychology, 66, 345376.

Bal, P.M., De Jong, S.B., Jansen, P.G.W., \& Bakker, A.B. (2012). Motivating employees to work beyond retirement: a multi-level study of the role of I-deals and unit climate. Journal of Management Studies, 49, 306-331.

Bal, P.M., Kooij, D.T.A.M., \& De Jong, S.B. (2013). How do developmental and accommodative HRM enhance employee engagement and commitment? The role of psychological contract and SOC-strategies. Journal of Management Studies, 50, 545572.

Chang, S., Gong, Y., Way, S. A., \& Jia, L. (2013). Flexibility-oriented Hrm systems, absorptive capacity, and market responsiveness and firm innovativeness. Journal of Management, 39(7), 1924-1951.

Chen, J., \& Li, W. (2015). The relationship between flexible Human resource management and Enterprise innovation Performance: A Study from Organizational Learning Capability Perspective in Information and Knowledge Management in Complex Systems (pp. 204-213). Springer international Publishing.

De Jong, J., \& Den Hartog, D. (2010). Measuring innovative work behaviour. Creativity and Innovation Management, 19(1), 23-36.

De La Lastra, S. f. P., martin-Alcazar, f., \& Sanchez-Gardey, G. (2014). Functional flexibility in Human resource management Systems: Conceptualization and measurement. International Journal of Business Administration, 5(1), 1-14.

Herrbach, O., Mignonac, K., Vandenberghe, C., \& Negrini, A. (2009). Perceived HRM practices, organizational commitment, and voluntary early retirement among latecareer managers. Human Resource Management, 48, 895-915.

Hult, G. T. M., Hurley, R. F., \& Knight, G. A. (2004). Innovativeness: Its antecedents and impact on business performance. Industrial Marketing Management, 33(5), 429-438

Jiang, J., Wang, S., \& Zhao, S. (2012). Does HRM facilitate employee creativity and organizational innovation? A study of Chinese firms. The International Journal of Human Resource Management, 23(19), 4025-4047.

Kozica, A., \& Kaiser, S. (2012). A sustainability perspective on flexible Hrm: How to cope with paradoxes of contingent work. Management Revue, 23(3), 239-261.

Kumari, i. G., \& Pradhan, r. K. (2014). Human resource flexibility and Organizational Effectiveness: role of Organizational Citizenship Behaviour and Employee intent to Stay. International Journal of Business and Management Invention. 11(3), 43-51.

Lyons, S., \& Kuron, L. (2014). Generational differences in the workplace: A review of the evidence and directions for future research. Journal of Organizational Behavior, 35, S139-S157.

Ma Prieto, i., \& Pilar Perez-Santana, m. (2014). Managing innovative work behavior: the role of human resource practices. Personnel Review, 43(2), 184-208.

Martínez Sánchez, A., Vela Jiménez, m. J., Pérez Pérez, m., \& de Luis Carnicer, P. (2011). The dynamics of labour flexibility: relationships between employment type and innovativeness. Journal of Management Studies, 48(4), 715-736. 
Twenge, J.M., Campbell, S.M., \& Freeman, E.C. (2012). Generational differences in young adults' life goals, concern for others, and civic orientation, 1966-2009. Journal of Personality and Social Psychology, 102, 1045-1062.

Twenge, J.M., Campbell, S.M., Hoffman, B.J., \& Lance, C.E. (2010). Generational differences in work values: leisure and extrinsic values increasing, social and intrinsic values decreasing. Journal of Management, 36, 1117-1142. 